Sholihin, Y. • E. Suminar · Rizky W.H. • Pitaloka G.G.

\title{
Pertumbuhan eksplan meristem bawang putih (Allium sativum L.) kultivar Tawangmangu pada berbagai komposisi kinetin dan $\mathrm{GA}_{3}$ in vitro
}

\author{
Meristem explants growth of garlic (Allium sativum L.) Cv. \\ tawangmangu on various compositions of kinetin and ga ${ }_{3}$ in vitro
}

Diterima : 15 November 2016/Disetujui : 15 Desember 2016 / Dipublikasikan : 30 Desember 2016

CDepartment of Crop Science, Padjadjaran University

\begin{abstract}
Garlic is an important commodity in Indonesia. Indonesia is the largest country on importing garlic. Conventional seed production technique is one of the limiting factors for optimal development and deployment of garlic seeds. Seed production in vitro can be used as an alternative method of seed multiplication for superior cultivars source. This study was aimed to get the best composition of kinetin and $\mathrm{GA}_{3}$ on MS medium for meristem explants growthin vitro. Research was conducted from April to July 2015 in the Tissue Culture Laboratory of Horticulture and Miscellaneous Seeds Development Center Pasir Banteng, District Jatinangor, Sumedang, West Java. Explants used in this research were meristem of garlic cv Tawangmangu. Experimental design used was a completely randomized design (CRD) with 12 treatments and 3 replications. Medium used was Murashige and Skoog ( MS ) with the addition of growth regulators Kinetin $\left(0,0 \mathrm{mg} \mathrm{L}^{-1}\right.$; $\left.1,5 \mathrm{mg} \mathrm{L}^{-1} ; 3,0 \mathrm{mg} \mathrm{L}^{-1} ; 4,5 \mathrm{mg} \mathrm{L}^{-1}\right)$ and $\mathrm{GA}_{3}\left(0,0 \mathrm{mg}^{-1}\right.$ $\left.\mathrm{L}^{-1} ; 0,5 \mathrm{mg} \mathrm{L}^{-1} ; 1,0 \mathrm{mg} \mathrm{L}^{-1}\right)$. Results showed that Kinetin and $\mathrm{GA}_{3}$ compositions treatment on MS medium had significant effects on the meristem explantsgrowth of Garlic cv Tawangmangu in vitro, and the best treatment for leaf number was 4,5 $\mathrm{mg} \mathrm{L}^{-1} \mathrm{Kin}+1,0 \mathrm{mg} \mathrm{L}^{-1} \mathrm{GA}_{3}$, and the media without kinetin gave a better effect on shoot height, root number and root length of meristem explant growth of garlic (Allium sativum L.) cv Tawangmangu in vitro.
\end{abstract}

Keywords: $\mathrm{GA}_{3} \cdot$ Garlic cv Tawangmangu $\cdot$ In Vitro - Kinetin · Meristem explant · MS Medium

Dikomunikasikan oleh Sosiawan Nusifera

Sholihin, Y. ${ }^{1}$ - E. Suminar ${ }^{2} \cdot$ Rizky W.H. $^{2}$. Pitaloka G.G. ${ }^{3}$

${ }^{1}$ Alumni Program Studi Agroteknologi, Faperta Unpad

2Dosen Fakultas Pertanian Universitas Padjadjaran

3Staf Balai Pengembangan Benih Hortikultura dan Aneka

Tanaman

Korespondensi e-mail:erni.suminar@unpad.ac.id
Sari Bawang putih merupakan komoditas penting di Indonesia. Indonesia merupakan negara terbesar pengimpor bawang putih. Permasalahan yang dihadapi dalam teknik produksi benih secara konvensional menjadi salah satu faktor pembatas tidak optimalnya pengembangan dan penyebaran benih tersebut. Produksi benih in vitro dapat dijadikan sebagai metode alternatif dalam perbanyakan benih sumber kultivar unggul. Penelitian ini bertujuanuntuk mendapatkan komposisi kinetin dan $\mathrm{GA}_{3}$ terbaik pada media dasar MS untuk regenerasi eksplan meristemsecara in vitro. Penelitian dilaksanakan di Laboratorium Kultur Jaringan Balai Pengembangan Benih Hortikultura dan Aneka Tanaman Pasir Banteng, Kecamatan Jatinangor, Kabupaten Sumedang, Provinsi Jawa Barat, yang berlangsung dari bulan April hingga Juli 2015. Eksplan yang digunakan adalah meristem bawang putih kultivar Tawangmangu. Rancangan percobaan yang digunakan adalah Rancangan Acak Lengkap (RAL) dengan 12 perlakuan dan 3 ulangan. Media yang digunakan adalah Murashige dan Skoog (MS) dengan penambahan zat pengatur tumbuh Kinetin $\left(0,0 \mathrm{mg} \mathrm{L}^{-1} ; 1,5 \mathrm{mg} \mathrm{L}^{-1} ; 3,0 \mathrm{mg} \mathrm{L}^{-1}\right.$; $\left.4,5 \mathrm{mg} \mathrm{L}^{-1}\right)$ dan $\mathrm{GA}_{3}\left(0,0 \mathrm{mg} \mathrm{L}^{-1} ; 0,5 \mathrm{mg} \mathrm{L}^{-1} ; 1,0 \mathrm{mg} \mathrm{L}^{-}\right.$ 1).Perlakuan komposisi Kinetin dan $\mathrm{GA}_{3}$ pada media MS memberikan pengaruh nyata terhadap pertumbuhan bawang putih kultivar Tawangmangu in vitro, dan perlakuan yang terbaik diperoleh pada perlakuan $4,5 \mathrm{mg} \mathrm{L}^{-1} \mathrm{Kin}+1,0 \mathrm{mg} \mathrm{L}^{-}$ ${ }^{1} \mathrm{GA}_{3}$ untuk peubah jumlah daun, tetapi perlakuan media tanpa kinetin memberikan pengaruh yang lebih baik terhadap tinggi tunas, jumlah akar, dan panjang akar pada pertumbuhan eksplan meristem bawang putih Kultivar Tawangmangu in vitro.

Kata kunci: Bawang Putih Kultivar Tawangmangu $\cdot$ Eksplan meristem $\cdot \mathrm{GA}_{3} \cdot \mathrm{In}$ Vitro $\cdot$ Kinetin $\cdot$ Media MS 


\section{Pendahuluan}

Bawang putih (Allium sativum L.) merupakan salah satu tanaman hortikultura yang termasuk ke dalam famili Alliaceae. Tanaman ini termasuk tanaman rempah utama di Indonesia sebagai penyedap masakan, selain itu bawang putih juga digunakan sebagai bahan obat dan bahan kosmetik menjadikan komoditas ini mempunyai tingkat konsumsi yang besar. Konsumsi yang besar ini tidak diimbangi dengan ketersediaan dalam negeri yang memadai sehingga kegiatan impor pun tidak dapat terelakan. Berdasarkan data Food and Agriculture Organization disingkat FAO (2014) Indonesia merupakan negara pengimpor bawang putih terbesar di dunia. Hal ini membuktikan bahwa bawang putih merupakan komoditas yang sangat penting di Indonesia.

Mengingat pentingnya komoditas bawang putih di Indonesia maka perlu dilakukan peningkatan produksi bawang putih untuk memenuhi kebutuhan dalam negeri. Badan Pusat Statistik dan Direktorat Jenderal Hortikultura (2014) melaporkan bahwa produksi bawang putih di Indonesia pada tahun 2014 adalah sebanyak 16.893 ton dengan luas panen 1.913 ha. Jumlah ini hanya mampu memenuhi $5 \%$ dari jumlah total kebutuhan bawang putih dalam negeri. Salah satu upaya peningkatan produksi bawang putih adalah dengan perluasan areal penanaman bawang putih, sehingga diperlukan bibit berkualitas dalam jumlah besar.

Menurut Wibowo (2009), penyebab rendahnya produktivitas bawang putih di Indo-nesia diantaranya adalah rendahnya kualitas bibit bawang putih yang digunakan, jamur dan virus penyebab penyakit pada bawang putih, kurang optimumnya lingkungan tumbuh, dan kehilangan hasil akibat teknik penyimpanan yang kurang memadai. Penggunaan benih asal dengan kultivar yang tidak jelas dari generasi ke generasi juga merupakan salah satu penyebab rendahnya produktivitas bawang putih di Indonesia, padahal terdapat banyak bawang putih kultivar lokal yang bisa dikembangkan. Salah satunya adalah bawang putih dataran tinggi kultivar Tawangmangu yang berasal dari Malang, Jawa Timur yang memiliki bentuk umbi bulat telur, ujung meruncing, dengan dasar yang datar. Umbi bawang kultivar ini memiliki potensi hasil $8-12$ ton/hektar dan merupakan salah satu kultivar lokal yang memiliki potensi hasil tertinggi (Samadi, 2000).

Permasalahan lainnya terletak pada sifat bawang putih yang merupakan tanaman steril secara seksual sehingga perbanyakan tanaman ini harus dilakukan secara vegetatif, sedangkan perbanyakan vegetatif secara konvensional masih dinilai kurang efektif karena satu umbi hanyadapat menghasilkan satu tanaman (Dirjen Hortikultura, 2010). Selain itu perbanyakan dengan metode ini memungkinkan terbawanya virus ke generasi selanjutnya. Hal itu juga yang menyebabkan perbanyakan bawang putih skala besar sulit dilakukan karena terbatasnya ketersediaan umbi bibit (Roksana et al., 2002).

Rendahnya ketersediaan bibit bawang putih dapat diupayakan dengan teknik perbanyakan secara in vitro atau biasa disebut teknik kultur jaringan. Kultur jaringan merupakan teknik propagasi tanaman secara in vitro dan dalam kondisi yang steril. Salah satu jenis eksplan yang biasa digunakan dalam kultur jaringan adalah jaringan meristematik tanaman atau biasa disebut kultur meristem (Karjadi dan Buchori, 2007), selain untuk perbanyakan tanaman, teknik kultur meristem ini juga dipergunakan untuk mengeliminasi virus dari jaringan tanaman. Penggunaan meristem dalam menghasilkan planlet yang terbebas dari virus disebabkan tidak adanya plasmodesmata, pembelahan sel yang cepat, adanya zat inhibitor, serta stabilitas genetik (Alam et al., 2010).

Media dasar yang banyak digunakan dalam kultur jaringan adalah Murashige and Skoog (media MS). Keunggulan media MS terdapat pada kandungan konsentrasi nutrisinya yang lebih tinggi dibandingkan dengan media dasar lainnya diantaranya adalah Media MS mengandung 1120,52 $\mathrm{mg} \mathrm{L}^{-1}$ nitrogen dalam bentuk $\mathrm{NO}_{3}{ }^{-}$dan $812,37 \mathrm{mg} \mathrm{L}^{-1}$ nitrogen dalam bentuk $\mathrm{NH}_{4}{ }^{+}$(Karjadi dan Buchori, 2008), selain media yang tepat, kombinasi zat pengatur tumbuh (ZPT) yang tepat juga merupakan salah satu faktor yang menentukan keberhasilan dalam kultur jaringan.

Zat pengatur tumbuh yang digunakan dalam percobaan ini adalah Kinetin dan $\mathrm{GA}_{3}$. Menurut Abidin (1994), kinetin termasuk hormon kinetin yang dapat memacu pembelahan sel pada bagian ujung tunas dan mengubahnya menjadi meristem yang aktif tumbuh, sedangkan $\mathrm{GA}_{3}$ merupakan salah satu jenis hormon giberelin yang dapat membantu eksplan untuk mensintesis auksin endogen (George dan Sherrington, 1984), selain itu $\mathrm{GA}_{3}$ juga dilaporkan dapat membantu pembentukan dan pemanjangan tunas (Rahman et al., 2006). Hasil penelitian Alam et al. (2010) pada eksplan meristem ubi jalar, menyatakan bahwa peng- 
gunaan kombinasi $\mathrm{GA}_{3}$ dan kinetin efektif dalam menginduksi pembentukan tunas serta perpanjangan tunas.

\section{Bahan dan Metode}

Penelitian ini dilaksanakan di Laboratorium Kultur Jaringan Balai Pengembangan Benih Hortikultura dan Aneka Tanaman Pasir Banteng, Kecamatan Jatinangor, Kabupaten Sumedang, Provinsi Jawa Barat. Percobaan dilaksanakan pada bulan April sampai Juli 2015.

Bahan yang digunakan dalam percobaan ini adalah benih bawang putih kultivar Tawangmangu, media dasar MS, Kinetin, $\mathrm{GA}_{3}$, agar-agar, gula pasir, akuades, alkohol $95 \%$, spiritus, tissue, plastik tahan panas dan karet.

Alat-alat yang digunakan dalam pembuatan media yaitu timbangan analitik, erlenmeyer, pipet dan volume pipet, beaker glass, botol kultur $100 \mathrm{ml}$, hot plate magnetic stirrer, plastik tahan panas, karet gelang, $\mathrm{pH}$ meter, autoclave, gelas ukur, dan oven. Pada tahap penanaman, alat-alat yang digunakan adalah Laminar Air Flow (LAF), petridish, pinset, scalpel blade, sprayer dan lampu spiritus, kemudian alat-alat yang dibutuhkan dalam ruang kultur adalah lampu fluorescent TL 40 Watt, rak kultur dan termohigrometer, sedangkan pada tahap pengamatan alat dan bahan yang dibutuhkan adalah alat tulis, penggaris, millimeter blok dan kamera.

Metode penelitian yang digunakan adalah metode eksperimen dengan menggunakan Rancangan Acak Lengkap (RAL) yang terdiri dari 12 perlakuan, 3 ulangan, dan masing-masing perlakuan terdiri dari 3 unit. Adapun 12 kombinasi perlakuannya yaitu, $\mathrm{A}=0,0 \mathrm{mg} \mathrm{L}^{-1}$ $\mathrm{Kin}+0,0 \mathrm{mg} \mathrm{L}^{-1} \mathrm{GA}_{3}, \mathrm{~B}=0,0 \mathrm{mg} \mathrm{L}^{-1} \mathrm{Kin}+0,5 \mathrm{mg}$ $\mathrm{L}^{-1} \mathrm{GA}_{3}, \mathrm{C}=0,0 \mathrm{mg} \mathrm{L}^{-1} \mathrm{Kin}+1,0 \mathrm{mg} \mathrm{L}^{-1} \mathrm{GA}_{3}, \mathrm{D}=$ $1,5 \mathrm{mg} \mathrm{L}^{-1} \mathrm{Kin}+0,0 \mathrm{mg} \mathrm{L}^{-1} \mathrm{GA}_{3}, \mathrm{E}=1,5 \mathrm{mg} \mathrm{L}^{-1}$ Kin + 0,5 mg L-1 $\mathrm{GA}_{3}, \mathrm{~F}=1,5 \mathrm{mg} \mathrm{L}^{-1} \mathrm{Kin}+1,0 \mathrm{mg}$ $\mathrm{L}^{-1} \mathrm{GA}_{3}, \mathrm{G}=3,0 \mathrm{mg} \mathrm{L}^{-1} \mathrm{Kin}+0,0 \mathrm{mg} \mathrm{L}^{-1} \mathrm{GA}_{3}, \mathrm{H}=$ $3,0 \mathrm{mg} \mathrm{L}^{-1} \mathrm{Kin}+0,5 \mathrm{mg} \mathrm{L}^{-1} \mathrm{GA}_{3}, \mathrm{I}=3,0 \mathrm{mg} \mathrm{L}^{-1} \mathrm{Kin}$ $+1,0 \mathrm{mg} \mathrm{L}^{-1} \mathrm{GA}_{3}, \mathrm{~J}=4,5 \mathrm{mg} \mathrm{L}^{-1} \mathrm{Kin}+0,0 \mathrm{mg} \mathrm{L}^{-1}$ $\mathrm{GA}_{3}, \mathrm{~K}=4,5 \mathrm{mg} \mathrm{L}^{-1} \mathrm{Kin}+0,5 \mathrm{mg} \mathrm{L}^{-1} \mathrm{GA}_{3}, \mathrm{~L}=4,5$ $\mathrm{mg} \mathrm{L}^{-1} \mathrm{Kin}+1,0 \mathrm{mg} \mathrm{L}^{-1} \mathrm{GA}_{3}$.

Pengujian pengaruh perlakuan dilakukan dengan analisis varians pada taraf kepercayaan $5 \%$, apabila hasil analisis menunjukkan pengaruh yang nyata, maka pengujian dilanjutkan dengan uji Scott-Knott pada taraf kepercayaan 5 \% (Gomez dan Gomez, 1995).

\section{Hasil dan Pembahasan}

Jumlah tunas. Hasil pengamatan pada Tabel 1 menunjukkan bahwa komposisi Kinetin dan $\mathrm{GA}_{3}$ memberikan hasil tunas tunggal. Pertumbuhan tunas pada penelitian ini mulai tampak pada minggu ke-2 pengamatan.

Tabel 1. Pengaruh Konsentrasi Kinetin dan $\mathrm{GA}_{3}$ terhadap Jumlah Tunas pada 2 MST, 4 MST, 6 MST dan 8 MST.

\begin{tabular}{ccccc}
\hline \hline \multirow{2}{*}{ Kode } & \multicolumn{4}{c}{ Jumlah Tunas (Buah) } \\
\cline { 2 - 5 } & 2 MST & 4 MST & 6 MST & 8 MST \\
\hline A & 1,00 & 1,00 & 1,00 & 1,00 \\
B & 1,00 & 1,00 & 1,00 & 1,00 \\
C & 1,00 & 1,00 & 1,00 & 1,00 \\
D & 1,00 & 1,00 & 1,00 & 1,00 \\
E & 1,00 & 1,00 & 1,00 & 1,00 \\
F & 1,00 & 1,00 & 1,00 & 1,00 \\
G & 1,00 & 1,00 & 1,00 & 1,00 \\
H & 1,00 & 1,00 & 1,00 & 1,00 \\
I & 1,00 & 1,00 & 1,00 & 1,00 \\
J & 1,00 & 1,00 & 1,00 & 1,00 \\
K & 1,00 & 1,00 & 1,00 & 1,00 \\
L & 1,00 & 1,00 & 1,00 & 1,11 \\
\hline \hline
\end{tabular}

Tabel 1 menunjukkan bahwa jumlah tunas pada 12 perlakuan hanya menghasilkan tunas tunggal pada 2 MST, 4 MST, dan 6 MST. Hal ini menunjukkan bahwa Kinetin dan $\mathrm{GA}_{3}$ yang diberikan dapat mendukung pertumbuhan tunas namun komposisi yang diberikan pada penelitian ini belum mampu memberikan pengaruh terhadap jumlah tunas yang terbentuk pada eksplan meristem bawang putih, namun pada 8 MST perlakuan L $\left(4,5 \mathrm{mg} \mathrm{L}^{-1}\right.$ Kinetin $+1,0 \mathrm{mg} \mathrm{L}^{-1} \mathrm{GA}_{3}$ ) menunjukkan rata-rata jumlah tunas 1,11 tunas. Sejalan dengan pernyataan Novianti et al., (2003) yang menjelaskan bahwa penambahan kinetin hingga 4,0 mg $\mathrm{L}^{-1}$ tidak memberikan pengaruh yang signifikan terhadap jumlah tunas pada penelitian induksi dan multiplikasi tunas kentang hitam asal meristem secara in vitro. Tabel 1. menunjukkan bahwa 11 perlakuan lainnya tidak menunjukkan peningkatan rata-rata jumlah tunas selama pengamatan (2 MST, 4 MST, 6 MST, dan 8 MST) atau tetap sama dengan rata-rata jumlah tunas yaitu 1,00 tunas.

Tinggi Tunas. Hasil analisis ragam terhadap peubah tinggi tunas eksplan bawang putih memperlihatkan bahwa perlakuan berba- 
gai konsentrasi kinetin dan $\mathrm{GA}_{3}$ memberikan pengaruh yang signifikan. Rata-rata tinggi tunas tersaji pada Tabel 2. Secara umum dapat dilihat bahwa perlakuan A $\left(0,0 \mathrm{mg} \mathrm{L}^{-1} \mathrm{Kin}+0,0 \mathrm{mg} \mathrm{L}^{-1}\right.$ $\mathrm{GA}_{3}$ ) memberikan pengaruh relatif lebih baik terhadap angka rata-rata tinggi tunas pada 4 MST, 6 MST, dan 8 MST karena menunjukkan angka paling tinggi dibandingkan dengan perlakuan lainnya, sedangkan perlakuan L $(4,5$ mg L-1 Kin $\left.+1,0 \mathrm{mg} \mathrm{L}^{-1} \mathrm{GA}_{3}\right)$ menunjukkan angka rata-rata tinggi tunas paling rendah pada 2 MST, 4 MST, 6 MST, dan 8 MST dibandingkan perlakuan lainnya.

Tabel 2. Pengaruh Konsentrasi Kinetin dan $\mathrm{GA}_{3}$ terhadap Tinggi Tunas pada 2 MST, 4 MST, 6 MST dan 8 MST.

\begin{tabular}{crrrr}
\hline \hline \multirow{2}{*}{ Perlakuan } & \multicolumn{4}{c}{ Tinggi Tunas (cm) } \\
\cline { 2 - 5 } & 2 MST & 4 MST & 6 MST & 8 MST \\
\hline A & $7,92 \mathrm{a}$ & $9,98 \mathrm{a}$ & $11,77 \mathrm{a}$ & $13,26 \mathrm{a}$ \\
B & $7,74 \mathrm{a}$ & $9,09 \mathrm{~b}$ & $10,76 \mathrm{~b}$ & $11,77 \mathrm{~b}$ \\
C & $7,87 \mathrm{a}$ & $8,96 \mathrm{~b}$ & $10,27 \mathrm{~b}$ & $11,09 \mathrm{~b}$ \\
D & $7,29 \mathrm{~b}$ & $8,48 \mathrm{c}$ & $9,33 \mathrm{c}$ & $10,10 \mathrm{c}$ \\
E & $7,61 \mathrm{a}$ & $8,51 \mathrm{c}$ & $9,27 \mathrm{c}$ & $10,24 \mathrm{c}$ \\
F & $7,23 \mathrm{~b}$ & $8,43 \mathrm{c}$ & $8,93 \mathrm{c}$ & $9,88 \mathrm{c}$ \\
G & $7,35 \mathrm{~b}$ & $8,28 \mathrm{c}$ & $8,91 \mathrm{c}$ & $10,02 \mathrm{c}$ \\
H & $7,21 \mathrm{~b}$ & $8,30 \mathrm{c}$ & $8,92 \mathrm{c}$ & $9,66 \mathrm{c}$ \\
I & $7,27 \mathrm{~b}$ & $8,08 \mathrm{c}$ & $8,97 \mathrm{c}$ & $9,93 \mathrm{c}$ \\
J & $7,18 \mathrm{~b}$ & $7,92 \mathrm{~d}$ & $8,66 \mathrm{c}$ & $9,41 \mathrm{c}$ \\
K & $7,09 \mathrm{~b}$ & $7,79 \mathrm{~d}$ & $8,46 \mathrm{c}$ & $9,43 \mathrm{c}$ \\
L & $6,47 \mathrm{c}$ & $7,22 \mathrm{e}$ & $7,73 \mathrm{~d}$ & $8,50 \mathrm{~d}$ \\
\hline \hline
\end{tabular}

Keterangan : Angka yang ditandai oleh huruf yang sama pada kolom yang sama menunjukkan tidak berbeda nyata menurut Uji Scott Knott pada taraf 5 $\%$.

Perlakuan A yang merupakan perlakuan media MS tanpa zat pengatur tumbuh menunjukkan tinggi tunas yang relatif lebih tinggi dibandingkan dengan perlakuan lainnya. Penelitian sebelumnya yang dilakukan oleh Haque $e t$ al. (2003) menunjukkan hasil yang sama bahwa pertumbuhan tunas paling tinggi dihasilkan dalam media MS tanpa zat pengatur tumbuh pada kultur in vitro bawang putih kultivar lokal Bangladesh yang berasal dari eksplan meristem.

Penambahan jumlah tunas pada eksplan dengan pemberian konsentrasi kinetin tinggi (4,5 $\left.\mathrm{mg} \mathrm{L}^{-1}\right)$ diiringi dengan rendahnya tinggi tunas, demikian pula sebaliknya. Hal ini diduga diakibatkan oleh adanya kompetisi dalam penyerapan nutrisi dan kompetisi dalam ruang tumbuh. Kompetisi akan meningkat sejalan dengan meningkatnya jumlah tunas. Khumaida et al. (1995) menyatakan, kompetisi dapat terjadi diantara bagian-bagian tanaman pada tanaman yang sama dan disebut kompetisi intra tanaman (intraplant competition). Kompetisi disebabkan oleh dua faktor, yaitu terbentuknya organ baru diantara organ yang lain dan terbatasnya faktor pertumbuhan yang ada, antara lain nutrisi dan ruang tumbuh.

Jumlah Daun. Berdasarkan analisis ragam dapat diketahui bahwa pemberian perlakuan kinetin dan $\mathrm{GA}_{3}$ pada penelitian ini memberikan pengaruh yang signifikan terhadap jumlah daun (Tabel 3).

Tabel 3. Pengaruh Konsentrasi Kinetin dan $\mathrm{GA}_{3}$ terhadap Jumlah Daun pada 2 MST, 4 MST, 6 MST dan 8 MST.

\begin{tabular}{crrrr}
\hline \hline \multirow{2}{*}{ Perlakuan } & \multicolumn{5}{c}{ Jumlah Daun (helai) } \\
\cline { 2 - 5 } & 2 MST & 4 MST & 6 MST & 8 MST \\
\hline A & $1,00 \mathrm{~b}$ & $1,00 \mathrm{c}$ & $1,00 \mathrm{c}$ & $1,00 \mathrm{c}$ \\
B & $1,11 \mathrm{~b}$ & $1,11 \mathrm{c}$ & $1,11 \mathrm{c}$ & $1,28 \mathrm{c}$ \\
$\mathrm{C}$ & $1,11 \mathrm{~b}$ & $1,11 \mathrm{c}$ & $1,11 \mathrm{c}$ & $1,11 \mathrm{c}$ \\
$\mathrm{D}$ & $1,00 \mathrm{~b}$ & $1,00 \mathrm{c}$ & $1,00 \mathrm{c}$ & $1,00 \mathrm{c}$ \\
E & $1,11 \mathrm{~b}$ & $1,11 \mathrm{c}$ & $1,11 \mathrm{c}$ & $1,11 \mathrm{c}$ \\
F & $1,00 \mathrm{~b}$ & $1,00 \mathrm{c}$ & $1,00 \mathrm{c}$ & $1,11 \mathrm{c}$ \\
$\mathrm{G}$ & $1,39 \mathrm{a}$ & $1,50 \mathrm{~b}$ & $1,61 \mathrm{~b}$ & $1,72 \mathrm{~b}$ \\
$\mathrm{H}$ & $1,39 \mathrm{a}$ & $1,39 \mathrm{~b}$ & $1,39 \mathrm{~b}$ & $1,72 \mathrm{~b}$ \\
$\mathrm{I}$ & $1,33 \mathrm{a}$ & $1,56 \mathrm{~b}$ & $1,56 \mathrm{~b}$ & $1,78 \mathrm{~b}$ \\
$\mathrm{~J}$ & $1,33 \mathrm{a}$ & $1,89 \mathrm{a}$ & $2,33 \mathrm{a}$ & $2,56 \mathrm{a}$ \\
$\mathrm{K}$ & $1,33 \mathrm{a}$ & $1,89 \mathrm{a}$ & $2,50 \mathrm{a}$ & $2,72 \mathrm{a}$ \\
$\mathrm{L}$ & $1,33 \mathrm{a}$ & $1,89 \mathrm{a}$ & $2,33 \mathrm{a}$ & $2,78 \mathrm{a}$ \\
\hline \hline
\end{tabular}

Keterangan : Angka yang ditandai oleh huruf yang sama pada kolom yang sama menunjukkan tidak berbeda nyata menurut Uji Scott Knott pada taraf 5 $\%$.

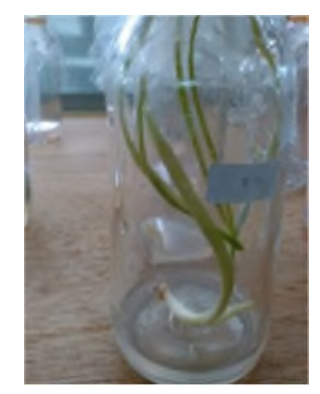

\section{Gambar 1. Jumlah Daun Perlakuan L pada 8 MST.}

Pada Tabel 3. dapat dilihat secara umum bahwa perlakuan $\mathrm{J}\left(4,5 \mathrm{mg} \mathrm{L}^{-1} \mathrm{Kin}+0,0 \mathrm{mg} \mathrm{L}^{-1}\right.$ $\left.\mathrm{GA}_{3}\right), \mathrm{K}\left(4,5 \mathrm{mg} \mathrm{L}^{-1} \mathrm{Kin}+0,5 \mathrm{mg} \mathrm{L}^{-1} \mathrm{GA}_{3}\right)$ dan $\mathrm{L}$ $\left(4,5 \mathrm{mg} \mathrm{L}^{-1} \mathrm{Kin}+1,0 \mathrm{mg} \mathrm{L}^{-1} \mathrm{GA}_{3}\right)$ menunjukkan perbedaan yang signifikan dengan angka yang lebih tinggi dibandingkan dengan perlakuan lainnya pada 4, 6, dan 8 MST namun belum menunjukkan perbedaan yang signifikan pada 2 MST. Tunas dengan perlakuan J, K, dan L yang 
memiliki konsentrasi kinetin paling tinggi menunjukkan jumlah daun yang lebih tinggi dibandingkan dengan perlakuan lainnya pada konsentrasi kinetin yang lebih rendah. Sesuai dengan pernyataan Avivi et al., (2013) yang menjelaskan bahwa peningkatan konsentrasi kinetin pada media akan meningkatkan jumlah daun yang terbentuk. Walaupun jumlah daun yang terbentuk banyak, tunas cenderung lebih pendek pada konsentrasi kinetin tinggi.

Jumlah Akar. Akar merupakan organ vegetatif utama yang memasok air, mineral dan bahan-bahan yang penting untuk pertumbuhan dan perkembangan tanaman (Gardner et al., 1991). Berdasarkan hasil pengamatan yang disajikan pada Tabel 5, data jumlah akar menunjukkan bahwa perlakuan yang diberikan berpengaruh signifikan terhadap jumlah akar pada 2 MST, 4 MST, 6 MST dan 8 MST.

Tabel 4. Pengaruh Konsentrasi Kinetin dan $\mathrm{GA}_{3}$ terhadap Jumlah Akar pada 2 MST, 4 MST, 6 MST dan 8 MST.

\begin{tabular}{ccccc}
\hline \multirow{2}{*}{ Perlakuan } & \multicolumn{4}{c}{ Jumlah akar } \\
\cline { 2 - 5 } & 2 MST & 4 MST & 6 MST & 8 MST \\
\hline A & 0,67 & 1,00 & 1,11 & 1,11 \\
B & 0,00 & 0,22 & 0,22 & 0,22 \\
C & 0,00 & 0,00 & 0,22 & 0,22 \\
D & 0,00 & 0,00 & 0,00 & 0,00 \\
E & 0,00 & 0,00 & 0,00 & 0,00 \\
F & 0,00 & 0,00 & 0,00 & 0,00 \\
G & 0,00 & 0,00 & 0,00 & 0,00 \\
H & 0,00 & 0,00 & 0,00 & 0,00 \\
I & 0,00 & 0,00 & 0,00 & 0,00 \\
J & 0,00 & 0,00 & 0,00 & 0,00 \\
K & 0,00 & 0,00 & 0,00 & 0,00 \\
L & 0,00 & 0,00 & 0,00 & 0,00 \\
\hline \hline
\end{tabular}

$\overline{\text { Keterangan : Data hasil pengamatan tidak diolah }}$ statistik karena sebaran data tidak normal.

Tabel 4. menunjukkan bahwa kultur yang menghasilkan jumlah akar relatif lebih tinggi pada media MS tanpa kinetin yaitu perlakuan $\mathrm{A}$ $\left(0,0 \mathrm{mg} \mathrm{L}^{-1} \mathrm{Kin}+0,0 \mathrm{mg} \mathrm{L}^{-1} \mathrm{GA}_{3}\right), \mathrm{B}\left(0,0 \mathrm{mg} \mathrm{L}^{-1}\right.$ Kin $\left.+0,5 \mathrm{mg} \mathrm{L}^{-1} \mathrm{GA}_{3}\right)$ dan C $\left(0,0 \mathrm{mg} \mathrm{L}^{-1} \mathrm{Kin}+1,0\right.$ $\left.\mathrm{mg} \mathrm{L}^{-1} \mathrm{GA}_{3}\right)$. Pertumbuhan akar pada perlakuan A mulai tampak pada pengamatan 2 MST, sedangkan perlakuan B mulai menunjukkan pertumbuhan akar pada umur tanaman 4 MST. Diduga auksin endogen pada mata tunas merangsang pembentukan akar yang cepat pada perlakuan MS tanpa ZPT (Gull et al., 2014). Perlakuan lain dengan pemberian kinetin tidak menunjukkan pembentukkan akar walaupun muncul tunas. Hal ini diduga disebabkan oleh aktivitas sitokinin eksogen konsentrasi tinggi yang diberikan dapat menghambat auksin endogen yang diproduksi pada tunas sehingga pembentukan akar terhenti (Karjadi dan Buchori, 2008). Menurut Salisbury dan Ross (1995) sitokinin dalam konsentrasi tinggi memungkinkan peningkatan konsentrasi gas etilen di dalam botol kultur sehingga menjadi penghambat pembentukan akar, namun faktor lain juga berpengaruh terhadap jumlah akar seperti keseimbangan ZPT yang diberikan dan interaksi antara hormon auksin endogen dengan sitokinin eksogen.

Pemberian GA3 dan kinetin menyebabkan pertumbuhan akar terhambat. Diduga disebabkan oleh aktifitas kinetin yang memengaruhi aktifitas $\mathrm{GA}_{3}$. George dan Sherrington (1984) menyatakan bahwa sitokinin biasanya tidak digunakan untuk tahap pengakaran pada mikropropagasi karena aktifitasnya dapat menghambat pembentukan akar, menghalangi pertumbuhan akar, dan menghambat pengaruh auksin terhadap inisiasi akar pada kultur jaringan sejumlah spesies tertentu.

Panjang Akar. Berdasarkan hasil pengamatan yang disajikan pada Tabel 5, data panjang akar akar menunjukkan bahwa perlakuan yang diberikan berpengaruh signifikan terhadap panjang akar pada 2 MST, 4 MST, 6 MST dan 8 MST.

Tabel 5. Pengaruh Konsentrasi Kinetin dan $\mathrm{GA}_{3}$ terhadap Panjang Akar pada 2 MST, 4 MST, 6 MST dan 8 MST.

\begin{tabular}{ccccc}
\hline \multirow{2}{*}{ Perlakuan } & \multicolumn{4}{c}{ Panjang akar (cm) } \\
\cline { 2 - 5 } & 2 MST & 4 MST & 6 MST & 8 MST \\
\hline A & 2,04 & 2,46 & 2,66 & 2,81 \\
B & 0,31 & 0,44 & 0,47 & 0,49 \\
C & 0,00 & 0,00 & 0,32 & 0,33 \\
D & 0,00 & 0,00 & 0,00 & 0,00 \\
E & 0,00 & 0,00 & 0,00 & 0,00 \\
F & 0,00 & 0,00 & 0,00 & 0,00 \\
G & 0,00 & 0,00 & 0,00 & 0,00 \\
H & 0,00 & 0,00 & 0,00 & 0,00 \\
I & 0,00 & 0,00 & 0,00 & 0,00 \\
J & 0,00 & 0,00 & 0,00 & 0,00 \\
K & 0,00 & 0,00 & 0,00 & 0,00 \\
L & 0,00 & 0,00 & 0,00 & 0,00 \\
\hline \hline
\end{tabular}

Keterangan : Data hasil pengamatan tidak diolah statistik karena sebaran data tidak normal.

Tabel 5. menunjukkan bahwa secara umum perlakuan A yang merupakan perlakuan media tanpa zat pengatur tumbuh memberikan pengaruh yang relatif lebih baik dibandingkan 
perlakuan lainnya. Perpanjangan akar pada perlakuan ini relatif lebih cepat dibandingkan perlakuan yang lain yaitu mencapai $13,26 \mathrm{~cm}$ dibandingkan perlakuan lainnya pada umur tanaman 8 MST (Gambar 2). Ali et al. (2009) menyatakan bahwa perlakuan media tanpa ZPT mampu mendorong auksin endogen dalam tanaman untuk merangsang pembentukan akar. Perlakuan lain dengan pemberian kinetin tidak menunjukkan pembentukan akar walaupun muncul tunas, diduga disebabkan oleh aktivitas sitokinin eksogen konsentrasi tinggi yang diberikan dapat menghambat auksin endogen yang diproduksi pada tunas sehingga pembentukan akar terhenti.

Penambahan $\mathrm{GA}_{3}$ pada media MS dengan konsentrasi $0,0 \mathrm{mg} \mathrm{L}^{-1}, 0,5 \mathrm{mg} \mathrm{L}^{-1}$ dan $1,0 \mathrm{mg} \mathrm{L}^{-1}$ pada penelitian ini diduga tidak memberikan pengaruh signifikan terhadap peubah panjang akar. Berbeda dengan hasil penelitian Farhatullah et al. (2007) yang menyatakan bahwa penambahan 0,248 $\mathrm{mg} \mathrm{L}^{-1} \mathrm{GA}_{3}$ pada media MS dapat mendukung penambahan panjang akar hingga 3,67 cm pada eksplan meristem kentang. Diduga pemberian kinetin yang merupakan jenis hormon sitokinin dapat menghambat kemampuan $\mathrm{GA}_{3}$ dalam menginduksi auksin endogen yang dapat memicu pertumbuhan akar. Didukung oleh pernyataan Lestari (2011) yang menyatakan bahwa dalam proses pembentukan organ seperti tunas atau akar terdapat interaksi antara zat pengatur tumbuh eksogen yang ditambahkan ke dalam media dengan zat pengatur tumbuh endogen.

\section{Kesimpulan}

Pemberian perlakuan 4,5 mg L-1 Kin $+1,0 \mathrm{mg} \mathrm{L}^{-1}$ $\mathrm{GA}_{3}$ dapat merangsang pembentukan tunas dan daun dari meristem eksplan bawang putih

\section{Daftar Pustaka}

Abidin, Z. 1994. Dasar-Dasar Pengetahuan Tentang Zat Pengatur Tumbuh. Bandung: Penerbit Angkasa, hal : 33-34

Alam, I., S. A. Sharmin, M. K. Naher, M. J. Alam. 2010. Effect of growth regulators on meristem culture and plantlet establishment in sweet potato [Ipomoea batatas (L.) Lam.]. Plant Omics Journal, 3(2):35-39.

Ali, A., Ahmad, T., dan Nadeem A. Abbasi. 2009. Effect of different concentrations of auxins on in vitro rooting of olive cultivar

"Moraiolo". Pak. J. Bot., 41(3): 1223-1231.

Avivi, S., Soedarmo, S.H., Prasetyo, P.A. 2013. Multiplikasi Tunas dan Aklimatisasi Tiga Varietas Pisang: Raja Nangka, Kepok, dan Mas. J. Hort. Indonesia 4(2):83-89.

Balai Penelitian Tanaman dan Sayuran. 2010. Pedoman Budidaya Tanaman Bawang Putih. Badan Penelitian dan pengembangan Tanaman, Kementrian Pertanian.

Direktorat Jenderal Hortikultura. 2010. Profil Bawang Putih. Direktorat Budidaya Tanaman Sayuran dan Biofarmaka. Direktorat Jenderal Hortikultura, Kementerian Pertanian.

Direktorat Jenderal Hortikultura. 2014. Produksi Tanaman Sayuran dan Buah-Buahan. Direktorat Jenderal Hortikultura, Kementerian Pertanian.

FAO Statistics. 2014. Indonesia Garlic Production [online] http://www.faostat.org. Diakses pada tanggal 25 September 2015.

FAO Statistics. 2014. Indonesia Garlic Demand [online] http://www.faostat.org. Diakses pada tanggal 25 September 2015.

Farhatullah., Z. Abass and S.J. Abbass. 2007. In vitro effect of gibberellic acid on morphogenesis $\mathrm{kf}$ potato explant. Int. J. Agri. Biol., 9(1): 181-182.

Gardner FP, Pearce RB, Mitchell RL. 1991. Fisiologi Tanaman Budidaya. Herawati Susilo, Penerjemah; Jakarta: Penerbit Universitas Indonesia.

George, E.F and P.D. Sherrington. 1984. Plant Propagation by Tissue Culture, Handbook and Directory of Comercial Laboratoryes. Easter Press, Englan, hal : 60-63

Gomez, K.A. dan Gomez A.A. (1995). Prosedur Statistik untuk Penelitian Pertanian. Edisi Kedua. Jakarta : UI - Press, hal :33 - 36.

Gull, I., Noreen, A., Aslam, MS., dan Muhammad Amin. 2014. Comparative effect of different pyhtohormones on the micropropagation of Allium sativum. Pak. J. Biochem. Mol. Biol., 2014; 47(1-2): 121-124.

Haque MS, Wada T and Hattori K. 2003. Shoot regeneration and bulblets formation from shoot and root meristem of Garlic $\mathrm{Cv}$ Bangladesh local. Asian J. Plant Sci., 2003; 2: 23-27.

Karjadi, A.K dan A. Buchori. 2008. Pengaruh komposisi media dasar, penambahan BAP, dan pikloram terhadap induksi tunas bawang merah. J. Hort. 18(1): 1-9. 
Karjadi, A.K. dan A. Buchori. 2007. Pengaruh NAA dan BAP terhadap pertumbuhan jaringan meristem bawang putih pada media B5. J. Hort. Vol. 17 (3): 217-223.

Khumaida, N., S. Ardie, C. Nugroho, Suwarto. 2011. Kinetin and Calcium Pantothenate Effects on Shoot Multiplication in In Vitro Cultured Cassava Var. Adira 2 and Adira 4. Proceedings of The 7th ACSA Conference.

Lestari, E.G. 2011.Peranan Zat Pengatur Tumbuh dalam Perbanyakan Tanaman melalui Kultur Jaringan. J. Agro Biogen7(1):63-68.

Novianti, A.V., S. Novianti, Murtado, H.A. Widianti, Hadiatmi. 2003. Induksi dan Multiplikasi Tunas Gembili dan Kentang Hitam Untuk Penyimpanan Secara Kultur In Vitro. Sem. Hasil Penelitian Rintisan dan Bioteknologi Tanaman. Bogor 23-24 Sept. 2003.
Rahman, MH., Haque, MS., Karim, MA., dan Masum Ahmed. 2006. Effects of Gibberellic Acid (GA3) on Breaking Dormancy in Garlic (Allium sativum L.). Int'1 J. of Agric. \& Biology. 1560-8530/2006/08-1-63-65.

Roksana, M. F. Alam, R. Islam and M. M. Hossain. 2002. In Vitro Bulblet Formation from Shoot Apex in Garlic (Allium sativum L). Department of Botany, University of Rajashahi, Rajashahi-6205.

Salisbury, F.B., dan C.W. Ross. 1995. Fisiologi Tumbuhan. Jilid 1 Terjemahan D. R. Lukman dan Sumaryo. ITB, Bandung, hal: 59-60.

Samadi, B. 2000. Usaha Tani Bawang Putih. Yogyakarta : Kanisius, hal 35-37.

Wibowo, S. 2009. Budidaya Bawang Putih, Merah, dan Bombay. Jakarta: PT Penebar Swadaya, hal : 32 . 